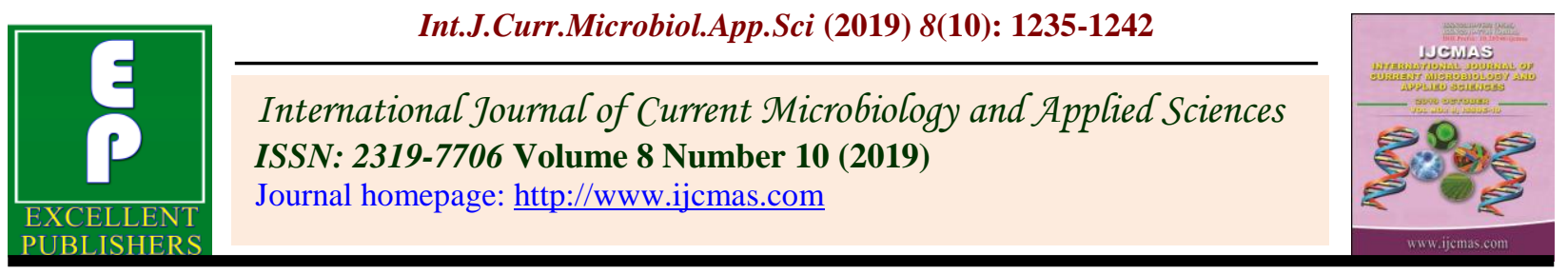

Original Research Article

https://doi.org/10.20546/ijcmas.2019.810.145

\title{
Extent of Utilization of Services Provided by Agricultural Technology and Information Centre (ATIC)
}

\author{
Davinder Singh* and R. K. Kalra \\ Department of Extension Education, Punjab Agricultural University, Ludhiana-141001, \\ Punjab, India
}

*Corresponding author

\begin{tabular}{|l|}
\hline Ke y w o r d s \\
Agricultural \\
Technology and \\
Information centre \\
(ATIC), Extent of \\
Utilization
\end{tabular}

A B S T R A C T

Agricultural Technology and Information Centre (ATIC) is a "single window" delivery system linking the various units of the institutions with farmers in decision making and problem solving exercises. An attempt was made to assess the services of ATIC availed by farmers and extent of utilization of these services. A total of 200 farmers were selected from the Ludhiana and Fazilka districts of Punjab as maximum number of farmers had visited ATIC from these districts. The findings revealed that majority of the farmers (58.50\%) took advice both on cultivation of crops and disease infestation from ATIC. Package of practices of rabi and kharif crops were availed by 60.50 per cent of farmers and majority of them were subscribers of monthly magazine Changi Kheti. About 60.00 per cent of the farmers used PAU helpline and out of these farmers, majority enquired about plant protection measures, improved varieties and seed availability. About technological products, majority of the farmers purchased seeds of wheat and paddy. It was observed that 42.00 per cent of the farmers had medium level, 32.00 per cent were in low level and 25.50 per cent had high level of extent of utilization.

\section{Introduction}

Research organizations are mainly focusing on the development of environmentally and socially compatible technologies for the resource poor farmers to improve their present farming system for increasing the production and productivity. This prime objective of the research organizations is not fulfilled unless the technologies reach the end users. Information about the technological advancements has to be brought to the notice of the end users for its successful adoption. The access of the farming community to the knowledge generation system is very weak and this needs a strong and effective linkage between development organizations and farming system (Sathiadhas and Immanue, 
2003). Dissemination of innovation should reach the right farmer at right place and at right time. There is a greater need for coordination between researchers and technology users. A higher degree of integration needs to be achieved by having a formal management mechanism linking scientists of different disciplines (though engaged in interdependent tasks) and the technology users. The linkage must have formal, permanent, mandated, facilitated mechanism. The establishment of an Agricultural Technology Information Centre will provide such a mechanism beyond the individual unit of a research institution to contribute to the dissemination of the information.

This will serve as a single window delivery system for services and products of research for the areas in which the concerned institute is involved (Nainwal, 2006). The establishment of ATIC in different regions of the country takes care of important aspect of location specific technology dissemination to farmers which helps to address the constraints within the existing technology transfer system. This further helps to accelerate the flow of skills from technology mentors to the farmers, which in turn contributes to the productivity and sustainability. Coordination between the researchers, extension workers and technology users is a felt need in every area of the rural development programmes in agriculture (Sathiadhas and Immanue, 2003). Hence an innovative transfer of technology mechanism named, Agricultural Technology Information Centre (ATIC) has been conceived and put into practice since 1998-99 under National Agricultural Technology Project (NATP) sponsored by World Bank and implemented through 40 ICAR Institutes and State Agricultural Universities (SAUs) located in various parts of the country (Anonymous 2014). An attempt was made in this study to assess extent of utilization of different services provided at ATIC, Punjab Agricultural University by the farmers.

\section{Materials and Methods}

A multistage sampling design was used for the selection of the respondents. A list of farmers who visited Agricultural Technology Information Centre (also known as Farmers Service Centre), PAU Ludhiana during the period of June 2011 to December 2013 was collected from the office of Directorate of Extension Education PAU, Ludhiana. A district wise list of the farmers who visited the ATIC was prepared. The total number of farmers who visited the Plant Clinic was 5359.

Two districts were selected purposively from where the maximum number of farmers had visited the ATIC i.e. Ludhiana (1484) and Fazilka (396). A total of 200 farmers were selected from the selected districts based on the probability proportional to number of the farmers visited from each district.

\section{Results and Discussion}

\section{Services of ATIC availed by farmers and their extent of utilization}

The different kinds of services of agricultural technology information centre can be categorized in following sub heads:

\section{Advisory/Diagnosis services}

The data presented in the Table 1 revealed that about 58.5 per cent of the farmers availed the advisory/diagnosis services of ATIC to sort out the problem relating to cultivation of different crops. The data further revealed that 58.5 per cent farmers took help of the experts to sort out the disease problems followed by insect $(35.5 \%)$ and nutrient deficiency $(25.5 \%)$ problems. Regarding weed related problems, only 8.5 per cent of farmers availed the help of experts of the ATIC. 
The results showed that among the farmers who availed advisory/diagnosis services, majority of them used these always. As many as 88.24 per cent, 87.32 per cent, 84.62 per cent, 76.47 per cent and 64.10 per cent of the farmers 'always' utilized the information obtained on weed infestation, insect attack, disease, nutrient deficiency and cultivation of crops, respectively. While 35.89 per cent and 23.52 per cent of the farmers 'sometime' used the information related to cultivation of crops and nutrient deficiency, respectively. It may be due to the fact that they consider insect-pest and weed as the major problem which needs to be dealt immediately. Regarding cultivation of crops and nutrient deficiency their own experience on farming may be contradictory with information given by the experts and they use these advices sometimes. The findings of the study are in line with the findings of Singh (1990), Sharma (1999) and Kumar and Singh (2007).

\section{PAU publications/farm literature services}

PAU publication/farm literature services such as Package of Practices for crops of Punjab, booklets, field problems of different crops, home science, monthly magazines and CD/DVD availed by the farmers and their utilization were studied. The data indicated that under Package of Practices, 60.5 per cent of farmers purchased Package of Practices of both kharif and rabi crops and 40.5 per cent of the farmers availed the package of practices of vegetables. A small number of farmers availed package of practices of fruit plants (11\%), mushroom cultivation (7\%) and flower and landscaping (6\%). A few of the farmers purchased package of practices on farm forest tree (2.5\%). Majority of the farmers 'sometimes' utilized package of practices on Kharif crops (86.78\%), rabi crops $(86.78 \%)$, mushroom cultivation (85.71\%), flower and landscaping (75\%), vegetable cultivation $(67.90 \%)$, farm forest tree $(60 \%)$ and fruit plant $(54.55 \%)$ (Table 2). The reason for majority of the farmers consulted package of practices on kharif and rabi crops is due to the fact that wheat and rice are the main crops grown in Punjab and moreover all the major crops of Punjab are covered in these packages of practices. Regarding booklets, about 18 per cent of the farmers purchased booklet of forage crops. This may be due to the fact that 28.5 per cent of the farmers engaged in dairy farming. A small number of the farmers i.e. 7.5 per cent and 3 per cent purchased booklets on poplar cultivation and pulses cultivation, respectively and all of them utilized these booklets 'sometimes'. It may be due to the reason that poplar is mainly grown in kandi area of Punjab.

An overview of publications on field problems indicated that about 21.5 per cent, 20 per cent and 14.5 per cent of the farmers' availed service of farm literature/publication related to field crops, vegetable and fruit crops, respectively. Majority of the farmers 'always' used publication of field problems on fruit crops $(79.31 \%)$ and vegetable crops (70\%). However, 79.07 per cent of the farmers 'sometimes' used literature related to field crops.

The reason for low percentage regarding publications on field problems may be that these are costly and after getting these publications farmers still need expert advice. The data regarding home science further indicated little more than one fourth $(28.5 \%)$ of the farmers availed services of farm literature related to preservation of fruits/vegetables and 23 per cent purchased book on delicious and nutritious recipes. Only 6.5 and 4.5 per cent of the farmers bought publications related to household equipments and clothing and textile, respectively. All the farmers 'sometime' used these publication/farm literature related to home science. The use of low percentage of 
publications on home science may be due to the reason that these are meant only for farm women, and in ATIC visitors, majority come for agricultural advice. Regarding PAU monthly magazines about half (49\%) of the farmers were subscriber of monthly magazine. majority of the farmers $(83.5 \%)$ availed PAU monthly magazine i.e. Changi Kheti. whereas only 2.5 per cent of the farmers availed progressive farming magazine. However 70.60 per cent and 40 per cent of the farmers 'sometimes' used Changi Kheti and progressive farming, respectively. A few of the farmers (1\%) purchased $\mathrm{CD}$ on grape cultivation. Low percentage of progressive farming adoption was due to language barrier as it is published in English.

The probe into data in Table 2 revealed that majority of the farmers 'sometimes' referred publication/literature. This might be due to reason that all the farmers were aware of agricultural practices. They used literature/publications only for new varieties, machinery and practices.

\section{Telephone helpline services}

The data given in the Table 3 revealed that nearly one fourth (26\%) of the farmers used Kisan Call Centre (KCC) for taking advice regarding farm related problems and out of these farmers majority (84.62\%) had 'sometimes' utilize information provided by $\mathrm{KCC}$. This may be due to the reason that KCC services are time consuming and have no direct contact with experts, only graduates deal with the farmers at first stage. Regarding PAU helpline about 58.5 per cent of the farmers availed PAU helpline service and majority (88.03\%) of them 'always' used expert's advice. This is because of the reason that farmers believe in PAU and also there are direct contacts with experts and farmers can visit ATIC for further queries if needed. Regarding information availed on helpline, two third (66.6\%) of the farmers did their enquiries about plant protection and all of them 'always' used this advice. While 60.68 per cent and 53.85 per cent used helpline service to get information on seed availability and improved varieties, respectively. Regarding their extent of utilization, information on crop production (95.56\%), kisan mela $(75 \%)$, seed availability $(71.83 \%)$ were always used by farmers while all the farmers sometimes used market related information followed by improved variety $(58.73 \%)$. High percentage of the farmers enquired about plant protection related information due to lack of in-depth knowledge regarding plant protection measures. The results were in track with the findings of Anupama (2005) and Dhanraj (2010).

\section{Technological products availed by the farmers}

The results of the study indicated (Table 4) that majority $(83 \%)$ of the respondents availed "seed sale" service of ATIC of crop seeds followed by vegetable seeds $(36.5 \%)$. Further, about 24.5 per cent and 18 per cent of the farmers purchased seeds of fodder crops and pulses, respectively. The more utilization of seed crops services may be due to the reason that the main crops grown in Punjab are wheat and rice. Regarding planting material about 26 per cent farmers availed vegetable nursery followed by ornamental plants (22\%). Very few percentage $(7 \%)$ of farmers purchased planting material of fruit plants.

Low percentage of sale in planting material is due to non-availability of nursery of fruit plants like mango, lichi, spota. Regarding bioproducts, 25 per cent and 24 per cent of the farmers purchased mushroom spawn and Rhizobium/Azotobacter culture, respectively. Very small percentage (9\% and $4.5 \%$ ) availed the service of bio-pesticide (Trichoderma) and bio-insecticide (Trichograma), respectively. 
Table.1 Advisory/diagnosis services availed by the farmers and extent of their utilization

\begin{tabular}{|c|c|c|c|c|c|c|c|c|}
\hline \multirow[t]{3}{*}{$\begin{array}{l}\text { Sr. } \\
\text { No. }\end{array}$} & \multirow[t]{3}{*}{$\begin{array}{l}\text { Advisory/Diagnosis } \\
\text { Services }\end{array}$} & \multicolumn{2}{|c|}{$\begin{array}{l}\text { Services } \\
\text { Availed }\end{array}$} & \multirow{3}{*}{$\begin{array}{c}\text { Average } \\
\text { Number } \\
\text { of } \\
\text { Times }\end{array}$} & \multicolumn{4}{|c|}{$\begin{array}{c}\text { Extent of Utilization of } \\
\text { Services }\end{array}$} \\
\hline & & \multirow[t]{2}{*}{ f } & \multirow[t]{2}{*}{$\%$ age } & & \multicolumn{2}{|c|}{ Always } & \multicolumn{2}{|c|}{ Sometimes } \\
\hline & & & & & $\mathbf{F}$ & $\%$ age & $\mathbf{f}$ & \%age \\
\hline 1. & Cultivation of crops & 117 & 58.50 & 1 & 75 & 64.10 & 42 & 35.89 \\
\hline 2. & Insect attack & 71 & 35.50 & 3 & 62 & 87.32 & 9 & 12.67 \\
\hline 3. & Nutrient deficiency & 51 & 25.50 & 2 & 39 & 76.47 & 12 & 23.52 \\
\hline 4. & Disease & 117 & 58.50 & 3 & 99 & 84.62 & 18 & 15.38 \\
\hline 5. & Weed & 17 & 8.50 & 2 & 15 & 88.24 & 2 & 11.76 \\
\hline
\end{tabular}

Table.2 PAU publications/farm literature services availed by the farmers and extent of their utilization

\begin{tabular}{|c|c|c|c|c|c|c|c|c|}
\hline \multirow[t]{3}{*}{$\begin{array}{l}\text { Sr. } \\
\text { No. }\end{array}$} & \multirow{3}{*}{\multicolumn{2}{|c|}{ Publications/Farm Literature }} & \multicolumn{2}{|c|}{$\begin{array}{l}\text { Services } \\
\text { Availed }\end{array}$} & \multicolumn{4}{|c|}{$\begin{array}{c}\text { Extent of Utilization of } \\
\text { Services }\end{array}$} \\
\hline & & & \multirow[t]{2}{*}{$\mathbf{f}$} & \multirow[t]{2}{*}{$\%$ age } & \multicolumn{2}{|c|}{ Always } & \multicolumn{2}{|c|}{ Sometimes } \\
\hline & & & & & $\mathbf{f}$ & \%age & f & \%age \\
\hline \multirow[t]{7}{*}{1} & \multirow[t]{7}{*}{ Package of Practices } & Kharif & 121 & 60.50 & 16 & 13.22 & 105 & 86.78 \\
\hline & & Rabi & 121 & 60.50 & 16 & 13.22 & 105 & 86.78 \\
\hline & & Vegetables & 81 & 40.50 & 26 & 32.10 & 55 & 67.90 \\
\hline & & Farm forest tree & 5 & 2.50 & 2 & 40.00 & 3 & 60.00 \\
\hline & & Fruit plants & 22 & 11.00 & 10 & 45.46 & 12 & 54.55 \\
\hline & & $\begin{array}{l}\text { Flower and } \\
\text { landscaping }\end{array}$ & 12 & 6.00 & 3 & 25.00 & 9 & 75.00 \\
\hline & & Mushroom cultivation & 14 & 7.00 & 2 & 14.29 & 12 & 85.71 \\
\hline \multirow[t]{3}{*}{2} & \multirow[t]{3}{*}{ Booklets } & Pluses cultivation & 6 & 3.00 & - & - & 6 & 100 \\
\hline & & Poplar cultivation & 15 & 7.50 & - & - & 15 & 100 \\
\hline & & Forage crops & 36 & 18.00 & - & - & 36 & 100 \\
\hline \multirow[t]{3}{*}{3} & \multirow[t]{3}{*}{ Field Problems } & Field crops & 43 & 21.50 & 9 & 20.93 & 34 & 79.07 \\
\hline & & Vegetables crops & 40 & 20.00 & 28 & 70.00 & 12 & 30.00 \\
\hline & & Fruit crops & 29 & 14.50 & 23 & 79.31 & 6 & 20.69 \\
\hline \multirow[t]{4}{*}{4} & \multirow[t]{4}{*}{ Home Science } & $\begin{array}{l}\text { Delicious \& nutritious } \\
\text { recipes }\end{array}$ & 46 & 23.00 & - & - & 46 & 100 \\
\hline & & $\begin{array}{l}\text { Preservation of } \\
\text { fruits/vegetables }\end{array}$ & 57 & 28.50 & - & - & 57 & 100 \\
\hline & & $\begin{array}{l}\text { Household } \\
\text { equipments }\end{array}$ & 13 & 6.50 & - & - & 13 & 100 \\
\hline & & Clothing \& textile & 9 & 4.50 & - & - & 9 & 100 \\
\hline \multirow[t]{2}{*}{5} & \multirow[t]{2}{*}{ Monthly Magazines } & Changi Kheti & 167 & 83.50 & 50 & 29.94 & 117 & 70.60 \\
\hline & & Progressive farming & 5 & 2.50 & 3 & 60.00 & 2 & 40.00 \\
\hline 6 & \multicolumn{2}{|c|}{ CD/DVDs } & 2 & 1.00 & 1 & 100 & - & - \\
\hline
\end{tabular}


Table. 3 Telephone helpline services availed by the farmers and the extent of their utilization

\begin{tabular}{|c|c|c|c|c|c|c|c|c|}
\hline \multirow{3}{*}{$\begin{array}{l}\text { Sr. } \\
\text { No. }\end{array}$} & \multirow[t]{3}{*}{ Telephone Helpline } & \multicolumn{2}{|c|}{ Services Availed } & \multirow{3}{*}{$\begin{array}{l}\text { Average } \\
\text { Number } \\
\text { of Times }\end{array}$} & \multicolumn{4}{|c|}{ Extent of Utilization of Services } \\
\hline & & \multirow[t]{2}{*}{ f } & \multirow{2}{*}{$\%$ age } & & \multicolumn{2}{|c|}{ Always } & \multicolumn{2}{|c|}{ Sometimes } \\
\hline & & & & & $\mathbf{F}$ & \%age & $\mathbf{f}$ & \%age \\
\hline i. & Kisan Call Centre & 52 & 26.00 & 2 & 8 & 15.39 & 44 & 84.62 \\
\hline \multirow[t]{7}{*}{ ii. } & PAU Helpline & 117 & 58.50 & 9 & 103 & 88.03 & 14 & 11.97 \\
\hline & Improved variety & 63 & 53.85 & 3 & 26 & 41.27 & 37 & 58.73 \\
\hline & Plant protection & 78 & 66.67 & 10 & 78 & 100 & - & - \\
\hline & Seed availability & 71 & 60.68 & 2 & 51 & 71.83 & 20 & 28.17 \\
\hline & Marketing & 17 & 14.53 & 1 & - & - & 17 & 100 \\
\hline & Crop production & 45 & 38.46 & 2 & 43 & 95.56 & 2 & 4.44 \\
\hline & Kisan Mela & 56 & 28.00 & 2 & 42 & 75 & 14 & 25 \\
\hline
\end{tabular}

Table.4 Distribution of farmers according to technological products and their utilization

\begin{tabular}{|c|c|c|c|c|c|c|c|c|c|}
\hline \multirow[t]{3}{*}{$\begin{array}{l}\text { Sr. } \\
\text { No. }\end{array}$} & \multirow{3}{*}{\multicolumn{2}{|c|}{ Technological products }} & \multicolumn{2}{|c|}{$\begin{array}{l}\text { Services } \\
\text { Availed }\end{array}$} & \multirow{3}{*}{$\begin{array}{c}\text { Averag } \\
\text { e } \\
\text { Numbe } \\
\text { r of } \\
\text { Times }\end{array}$} & \multicolumn{4}{|c|}{$\begin{array}{l}\text { Extent of Utilization of } \\
\text { Services }\end{array}$} \\
\hline & & & \multirow[t]{2}{*}{ f } & \multirow[t]{2}{*}{$\%$} & & \multicolumn{2}{|c|}{ Always } & \multicolumn{2}{|c|}{ Sometimes } \\
\hline & & & & & & f & $\%$ age & f & $\begin{array}{c}\% \text { ag } \\
\text { e }\end{array}$ \\
\hline \multirow[t]{4}{*}{1.} & \multirow[t]{4}{*}{ Seed } & Crop Seed & 168 & 83.00 & 3 & 168 & 100 & - & - \\
\hline & & Pulses & 36 & 18.00 & 1 & 36 & 100 & - & - \\
\hline & & Vegetable Seed & 73 & 36.50 & 4 & 73 & 100 & - & - \\
\hline & & Fodder Crops & 49 & 24.50 & 2 & 49 & 100 & - & - \\
\hline \multirow[t]{3}{*}{2.} & \multirow[t]{3}{*}{$\begin{array}{l}\text { Planting } \\
\text { Materials }\end{array}$} & $\begin{array}{l}\text { Ornamental } \\
\text { Plants }\end{array}$ & 44 & 22.00 & 2 & 44 & 100 & - & - \\
\hline & & Fruit Plants & 14 & 7.00 & 1 & 14 & 100 & - & - \\
\hline & & $\begin{array}{l}\text { Vegetable } \\
\text { Nursery }\end{array}$ & 52 & 26.00 & 2 & 52 & 100 & - & - \\
\hline \multirow[t]{4}{*}{3.} & \multirow[t]{4}{*}{$\begin{array}{c}\text { Bio- } \\
\text { products }\end{array}$} & $\begin{array}{l}\text { Rhizobium/ } \\
\text { Azotobacter } \\
\text { culture }\end{array}$ & 48 & 24.00 & 2 & 48 & 100 & - & - \\
\hline & & $\begin{array}{l}\text { Mushroom } \\
\text { spawn }\end{array}$ & 50 & 25.00 & 2 & 50 & 100 & - & - \\
\hline & & $\begin{array}{l}\text { Bio-pesticide } \\
\text { (Trichoderma) }\end{array}$ & 18 & 9.00 & 1 & 18 & 100 & - & - \\
\hline & & $\begin{array}{l}\text { Bio-insecticide } \\
\text { (Trichograma) }\end{array}$ & 9 & 4.50 & 2 & 9 & 100 & - & - \\
\hline \multirow[t]{2}{*}{4.} & \multirow{2}{*}{$\begin{array}{c}\text { Food } \\
\text { Technolog } \\
\text { y Related } \\
\text { Products }\end{array}$} & Squashes & 45 & 22.50 & 2 & 30 & 66.67 & 15 & 33.33 \\
\hline & & Honey & 66 & 33.00 & 1 & 11 & 16.67 & 55 & 83.33 \\
\hline
\end{tabular}


Table.5 Overall extent of utilization of ATIC services availed by the farmers

\begin{tabular}{|r|c|c|c|}
\hline $\begin{array}{r}\text { Sr. } \\
\text { No. }\end{array}$ & Extent of Utilization of Services & F age \\
\hline $\mathbf{1}$ & Low (1.2-1.47) & 51 & 25.50 \\
\hline $\mathbf{2}$ & Medium (1.47-1.68) & 84 & 42.00 \\
\hline $\mathbf{3}$ & High (1.68-1.9) & 65 & 32.50 \\
\hline
\end{tabular}

Fig.1 Distribution of the respondents on the basis of Overall extent of utilization

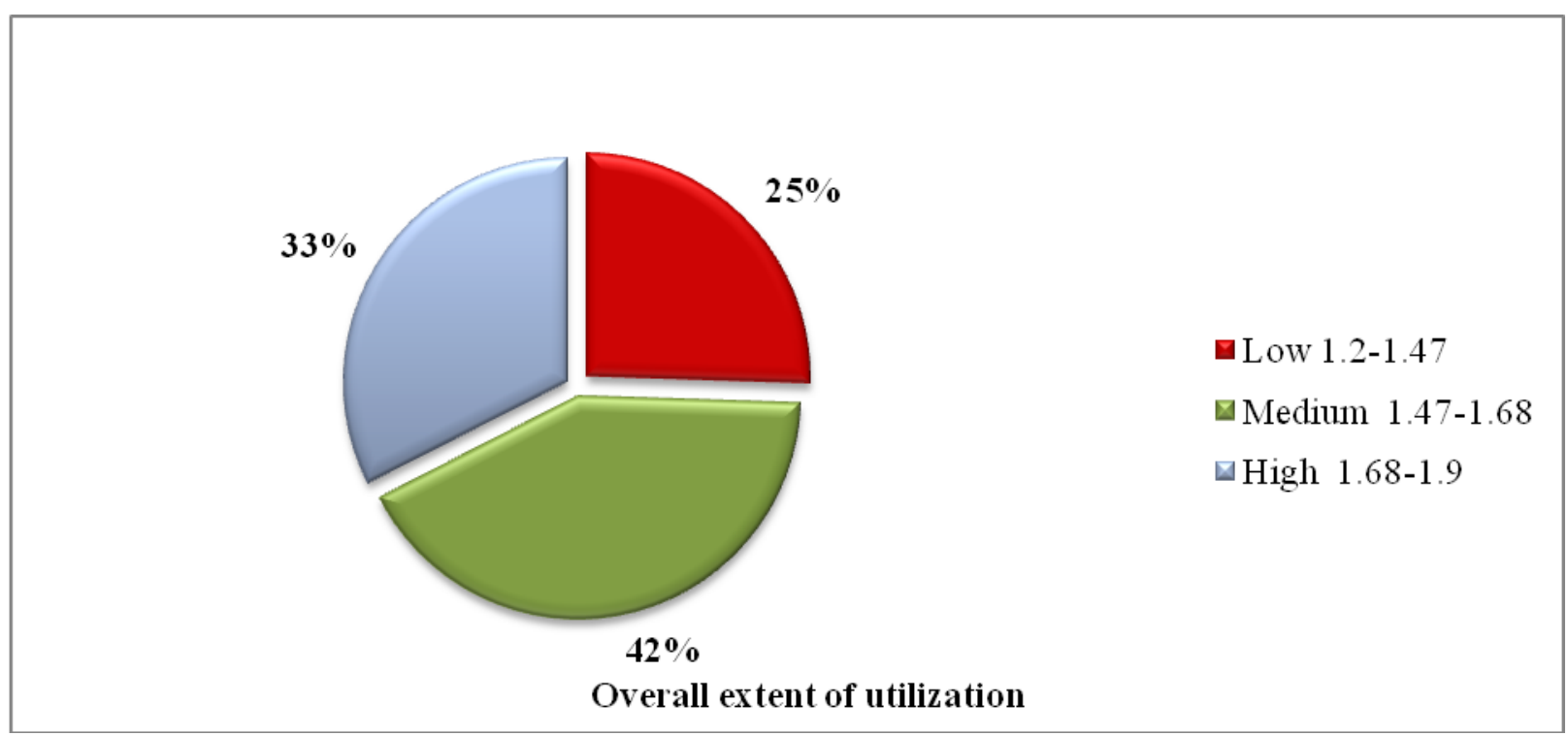

All of them always used bio-products. It may be due to the fact that farmers are coming forward for mushroom cultivation and it is becoming a popular crop in Punjab due to its easy cultivation and low investment. Low utilization of Rhizobium/Azotobacter culture is due to their use only in pulse crops. Less adoption of bio-pesticides may be due to their low efficiency in controlling diseases and insects/pests. The findings of this research are supported with those of Singh (1990), Sharma (1999) and Dhanraj (2010).

The data presented in Table 4 further reported the use of food technology products by the farmers. About one third (33\%) of the farmers purchased honey and they 'sometimes' $(83.33 \%)$ used it while 22.5 per cent of the farmers bought squashes and they utilized it 'always'.

\section{Overall extent of utilization}

The overall utilization score of each farmer were summed up regarding all the aspects of services provided by the ATIC and mean score was calculated. The total mean scores were classified into three categories by using cumulative cube root method.

The data in presented in Table 5 indicated that about 42 per cent of the farmers had medium level of utilization i.e. they always used services availed from ATIC whereas nearly one third $(32.5 \%)$ of the farmers had high extent of utilization and only 25.5 per cent had low level of utilization. Medium and low categories of farmers can be shifted to high category of extent of utilization by creating awareness among masses for services of ATIC. The results are contradictory to Pandey 
and Solanki (2014). The results have been also presented in Figure 1.

It can be concluded that majority of the farmers' availed advisory services both on cultivation of crops and disease infestation, services regarding farm literatures, technological products and helpline services provided by ATIC, Punjab agricultural university. Further, farmers had medium level of extent of utilization of these services.

\section{References}

Anonymous (2014) Agricultural Technology Information Centre (ATIC): Navsari, Retrieved from http://www.nau.in/ home.php?unit=atic\&info=Introductio $\mathrm{n}$ on $04-06-2014$.

Anupama (2005) The extent of utilization of Punjab Agricultural University farmers helpline by farmers and farm women of Punjab. M.Sc. Thesis, Punjab Agricultural University, Ludhiana, India.

Dhanraj (2010) Impact Assessment of ATIC run by SKRAU, Bikaner (Rajasthan)" M.Sc. (Ag.) Thesis, Swami Keshwanand Rajasthan Agricultural University, Bikaner (Rajasthan).

Kumar V and Singh B (2007) Impact of the Agricultural Technology Information Centre of Central Marine Fisheries Research Institute: Success Cases.
Indian J Ext Edu 43: 16-19.

Nainwal K (2006) Agricultural Technology Information Centre: A one stop shop/ information hub for farmers, Retrieved from http://aaqua.persistent. co.in/ aaqua/forum/ getattachment? attach=4912 on 04-04-2014.

Pandey M and Solanki A (2014) Utilization of Agricultural Technology Information Centre (ATIC) Facilities by Farm Families in Udham Singh Nagar District (Uttarakhand). Int $\mathbf{J}$ Sci and Res 3: 1011-14.

Sandhu A S, Butter N S and Bhatti D S (2005), Directorate of Extension Education: Tech Bull Pp 2-4. Punjab Agricultural University, Ludhiana, India.

Sathiadhas R and Immanue S (2003) Agricultural Technology Information Centre: activities and achievements. Pp 41. Central Marine Fisheries Research Institute, Cochin.

Sharma A K (1999) An appraisal of services rendered to the farmers by Plant Clinic, PAU Ludhiana. M.Sc. Thesis, Punjab Agricultural University, Ludhiana, India.

Singh T (1990) Marketing of services- A case study of PAU. Research project, Punjab Agricultural University, Ludhiana, India.

\section{How to cite this article:}

Davinder Singh and Kalra, R. K. 2019. Extent of Utilization of Services Provided by Agricultural Technology and Information Centre (ATIC). Int.J.Curr.Microbiol.App.Sci. 8(10): 1235-1242. doi: https://doi.org/10.20546/ijcmas.2019.810.145 